Research Article

\title{
The Association of Bladder Wall Thickness with Severity of Symptoms in Patients with Overactive Bladder
}

\section{Hubungan antara Ketebalan Dinding Vesika Urinari dengan Keparahan Gejala pada Pasien Overactive Bladder}

\author{
Ronny Adrian', Amir Fauzi', Nuswil Bernolian', Irsan Saleh ${ }^{2}$ \\ ${ }^{1}$ Department of Obstetrics and Gynecology \\ ${ }^{2}$ Medicine and Health Research Unit \\ Faculty of Medicine Universitas Sriwijaya/ \\ Dr. Mohammad Hoesin General Hospital \\ Palembang
}

\begin{abstract}
Objective: To investigate the association of bladder wall thickness (BWT) with severity of symptoms in overactive bladder patients in Obstetrics and Gynecology Department Dr. Mohammad Hoesin general hospital Palembang.

Methods: An analytical observational study was conducted at Gynecology clinic Dr. Mohammad Hoesin General Hospital Palembang from November 2015 to August 2016. Data were analyzed with SPSS 16.0 for Windows. Bivariate analysis with the Chi square and association Rank-Spearman test was used to assess the association between BWT and visual analog scale (VAS).

Results: Fourty subjects were included in the study. The mean BWT in the overactive bladder group was thicker compared to those without overactive bladder $(5.8522 \pm 0.5783$ vs $5.2176 \pm$ 0.67937). There was significant association between BWT and overactive bladder complaints. Abnormal group ( $\geq 5 \mathrm{~mm}$ ) had 12 times risk of overactive bladder compared to normal sample $(\leq 5 \mathrm{~mm})(\mathrm{p}=0.029, \mathrm{RR}=12)$.

Conclusion: Thus, the thickness of the urinary bladder wall measured with ultrasound examination (USG) can be used to assess the status and degree of urinary disorders in women with complaints of painful urinate and urinary disorders.

[Indones J Obstet Gynecol 2017; 5-4: 219-224]
\end{abstract}

Keywords: bladder wall thickness, detrusor overactivity, overactive bladder, visual analog scale

\begin{abstract}
Abstrak
Tujuan: Menilai hubungan ketebalan dinding vesika urinaria dengan Visual Analog Scale (VAS) pada penderita gangguan berkemih di Departemen Obstetrik dan Ginekologi RSUP Dr. Mohammad Hoesin Palembang.

Metode: Studi observasional analitik telah dilakukan di poliklinik Ginekologi RSUP Dr. Mohammad Hoesin Palembang dari November 2015 sampai Agustus 2016. Sebanyak 40 subjek penelitian yang memenuhi kriteria inklusi dimasukkan dalam penelitian. Data dianalisis dengan menggunakan program SPSS 16.0 dan dilakukan analisis bivariat dengan chi-square dan uji korelasi Rank-Spearman untuk menilai korelasi ketebalan dinding vesika urinaria dengan visual analog scale (VAS).

Hasil: Studi menunjukkan rerata ketebalan dinding vesika urinaria kelompok gangguan berkemih lebih tebal dibanding kelompok tanpa gangguan berkemih $(5,8522 \pm 0,5783$ vs 5,2176 $\pm 0,67937)$. Terdapat hubungan bermakna antara kategori ketebalan dinding vesika urinaria dengan keluhan gangguan berkemih, di mana kelompok sampel dengan tidak normal ( $\leq 5 \mathrm{~mm}$ ) berisiko $12 \mathrm{kali}$ mengalami gangguan berkemih dibanding kelompok sampel dengan BWT normal $(\leq 5 \mathrm{~mm})(p=0,029, R R=12)$.
\end{abstract}

Kesimpulan: Sehingga ukuran tebal dinding vesika urinaria dari hasil pemeriksaan (USG) dapat digunakan untuk menilai status dan derajat gangguan berkemih pada perempuan dengan keluhan nyeri dan gangguan berkemih.

[Maj Obstet Ginekol Indones 2017; 5-4: 219-224]

Kata kunci: detrusor overactivity (DO), ketebalan dinding vesika urinaria (BWT), gangguan berkemih, skala visual analog

Correspondence: Ronny Adrian.: ronnyadrian29@gmail.com

\section{INTRODUCTION}

Overactive bladder $(\mathrm{OAB})$ is a common urinary condition characterized by urinary urgency with or without urinary incontinence, frequent urination (the need to urinate 8 times or more in a period of 24 hours), and nocturia (waking up at night to urinate twice or more). The International Continence Society (ICS) is defined overactive bladder as a syndrome, consist in go furinary urgency with or without incontinence, usually accompanied with frequent urination and nocturia. ${ }^{1,2}$

A study conducted in England found that the overall prevalence of $\mathrm{OAB}$ in the general population was $12 \%$. This figure is roughly the same with other countries. Generally, the 
incidence of overactive bladder is approximately 20 to $40 \%$ of all urinary incontinence. Using urodynamic examination in patients with urinary incontinence, overactive bladder is found in about $24.4 \%$ cases, and this number keeps increasing with age. Previous studies show that $75 \%$ of male patients with urge incontinence and $44 \%$ of male patients with urinary frequency have detrusor overactivity (DO). A previous study conducted on $44 \%$ of women, $54.2 \%$ of patients with the symptoms of urinary disorders have a DO. However, these studies were carried out before the new ICS report was published. Thus, it was based on the old definition of urgency. ${ }^{1-4}$

Symptoms of urinary disorders include urinary frequency as much as 8 times or more in one day, or 1 time or more during the night; urgency to urinate which occurs suddenly, a strong desire to urinate immediately; urge incontinence, which is the inability to resist the urge to urinate. These symptoms may lead to various problems such as impaired physical activity and work, social interaction, psychological problems (depression), impaired sleep patterns, and sexual problems-all of which is a disruption to the quality of life. ${ }^{3-5}$

Some researchers have been working to find other diagnostic methods that are cheaper, easier, non-invasive, and reliable. Ultrasonography (USG) was found to meet these criteria, coupled with the advantage of not requiring the use of contrast material and X-ray exposure. USG is proven to be useful to evaluate urethro- vesical junction in stress urinary incontinence and may estimate the post-voiding residual volume. Measuring of bladder wall thickening with transvaginal ultrasound is expected to aid in diagnosing women with detrusor overactivity as well as those with stress urinary incontinence (SUI). ${ }^{6,7}$

In a study of 247 women with overactive bladder symptoms, Serati et al. (2010) found that BWT values in women with DO, measured using transvaginal ultrasound were significantly higher $(p$ $<0.0001$ ). They used a cut-off of $5.0 \mathrm{~mm}$ with a positive predictive value of $100 \%$. Panayi et al. (2010) conducted a study on 378 women with the average age of 56 years old, and concluded that the mean BWT is associated with symptoms of urinary disorders and mixed urinary incontinence (MUI), higher urination frequency of urination during the day and night, and greater visual analog scale (VAS). Detrusor overactivity is characterized by involuntary bladder-muscle contraction. Continuous contraction of detrusor muscle may led to thickening of the bladder wall. Thickening of the bladder wall will subsequently induce the sensation of pain caused by the decrease in bladder capacity, and urinary disorders characterized by frequency, nocturia, and urgency. Therefore, it is post-lated that there is a association between bladder wall thickness and a higher visual analog scale in overactive bladder patients. This study was proposed to test this association in Dr. Mohammad Hoesin Hospital Palembang, where a research on the association of BWT and VAS in patients with overactive bladder at Dr. Mohammad Hoesin Hospital Palembang or in South Sumatera has never been done before. ${ }^{8-11}$

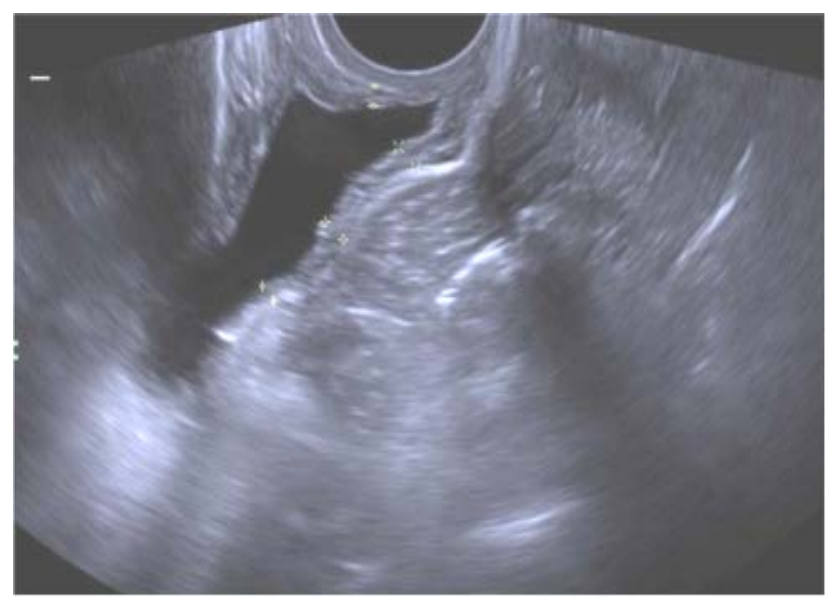

Figure 1. Transvaginal scan of the normal bladder wall showing measurements of the trigone and parts of the dome From Panayi. ${ }^{12}$
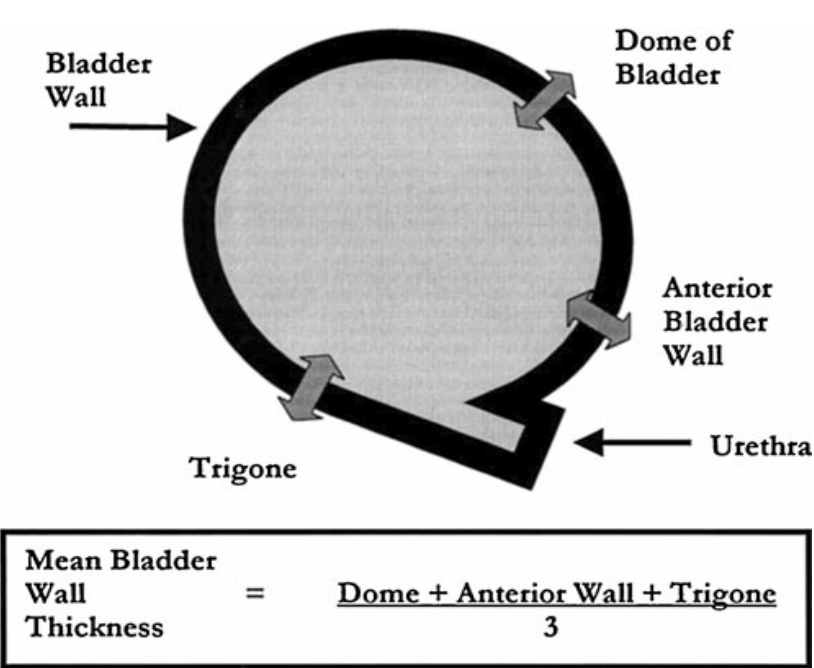

Figure 2. Bladder wall thickness From Panayi ${ }^{12}$ 


\section{METHODS}

This was a cross sectional study conducted at the gynecologic clinic of Dr. Mohammad Hoesin Hospital, Palembang, Indonesia. The data was gathered starting from November 2015 until August 2015.

Subjects were women with overactive bladder symptoms. The total sample in this study were 40 patients, which consisted of 17 controls and 23 cases. Data were analyzed using SPSS 16.0 and bivariate analysis using Chi-square and Spearman Rank association test were conducted to assess the association of BWT with VAS.

\section{RESULTS}

Mean BWT was thicker in the group with urinary disorders compared to those without urinary disorders (5.8522 \pm 0.5783 vs $5.2176 \pm 0.67937$ ). Table 1 shows the characteristics of the study subjects at the time of data collection. It appears that urinary disorders mostly occur at a young age ( $<40$ years) (65.2\%), on highly educated women (high school graduation) (47.8\%), women with ideal BMI (52.2\%), multiparous women (47.8\%), women with no history of CS or abortion (4.3\%), women with abnormal BWT (95.7\%), and all complained of painful urination (100\%).There was no significant difference in the characteristics of samples with and without urinary disorders, showing that the demographic characteristics bias has been successfully minimized in this study.

Table 1. Demographic Characteristics

\begin{tabular}{|c|c|c|c|c|}
\hline \multirow{2}{*}{ Variable } & \multicolumn{2}{|c|}{$\begin{array}{l}\text { Urinary disorders }(+) \\
\qquad(\mathrm{N}=23)\end{array}$} & \multicolumn{2}{|c|}{$\begin{array}{l}\text { Urinary disorders }(-) \\
(\mathrm{N}=17)\end{array}$} \\
\hline & $\mathbf{n}$ & $\%$ & $\mathbf{n}$ & $\%$ \\
\hline \multicolumn{5}{|l|}{ Age } \\
\hline Young & 15 & 65.2 & 8 & 47.1 \\
\hline Elders & 8 & 34.8 & 9 & 52.9 \\
\hline \multicolumn{5}{|l|}{ Residence } \\
\hline Urban area & 11 & 47.8 & 8 & 47.1 \\
\hline Rural area & 12 & 52.2 & 9 & 52.9 \\
\hline \multicolumn{5}{|l|}{ Education } \\
\hline Un educated & 1 & 4.3 & 0 & 0 \\
\hline $\begin{array}{l}\text { Elementry } \\
\text { school }\end{array}$ & 3 & 13 & 3 & 17.6 \\
\hline Junior school & 4 & 17.4 & 2 & 11.8 \\
\hline High school & 11 & 47.8 & 9 & 52.9 \\
\hline University & 4 & 17.4 & 3 & 17.6 \\
\hline
\end{tabular}

BMI

\begin{tabular}{lcccc} 
Underweight & 4 & 17.4 & 0 & 0 \\
Ideal & 12 & 52.2 & 10 & 58.8 \\
Overweight & 4 & 17.4 & 3 & 17.6 \\
Obese & 3 & 13 & 4 & 23.5 \\
Parity & & & & \\
Nullipara & 9 & 39.1 & 7 & 41.2 \\
Primipara & 3 & 13.1 & 4 & 23.5 \\
Multipara & 11 & 47.8 & 6 & 35.3 \\
History of CS & & & & \\
CS (-) & 22 & 95.7 & 17 & 100 \\
CS (+) & 1 & 4.3 & 0 & 0 \\
History of abor- & & & & \\
tion & & & & \\
(-) & 22 & 95.7 & 16 & 94.1 \\
$\quad+$ (+) & 1 & 4.3 & 1 & 5.9 \\
BWT category & & & & \\
Normal & 1 & 4.3 & 6 & 35.3 \\
Abnormal & 22 & 95.7 & 11 & 64.7 \\
Painful urination & & & & \\
Not Pain & 0 & 0 & 1 & 5.90 \\
Mild Pain & 19 & 82.6 & 11 & 82.4 \\
Moderate Pain & 3 & 13 & 2 & 11.8 \\
Severe Pain & 1 & 4.3 & 0 & 0 \\
\hline \hline
\end{tabular}

Table 2. Association between Urinary Disorders and Bladder Wall Thickness (BWT)

\begin{tabular}{lccccc}
\hline \hline \multirow{2}{*}{$\begin{array}{c}\text { BWT } \\
\text { category }\end{array}$} & $\begin{array}{c}\text { Urinary } \\
\text { disorder }\end{array}$ & $\begin{array}{c}\text { normal } \\
\text { urinary }\end{array}$ & $\mathbf{p}$ & RR \\
\cline { 2 - 4 } & $\mathbf{n}$ & $\mathbf{n}$ & & \\
\hline Abnormal $(\geq 5 \mathrm{~mm})$ & 22 & 11 & & \\
Normal $(\leq 5 \mathrm{~mm})$ & 1 & 6 & 0.029 & 12 \\
Total & 23 & 17 & & \\
\hline \hline
\end{tabular}

Fisher exact test, $p<0.05$.

Table 2 shows significant association between BWT categories and complaints of urinary disorders, where the sample group with abnormal BWT $(>5 \mathrm{~mm})$ has risk of experiencing urinary disorders 12 times higher compared to the group with normal BWT $(<5 \mathrm{~mm})(\mathrm{p}=0.029$, $\mathrm{RR}=12$ ).

Figure 3 shows significant association $(\mathrm{p}=$ $0.001, \mathrm{R}=0.269$ ) between BWT with a total OABSS, where the thicker the bladder wall, the greater the urinary disorders. 


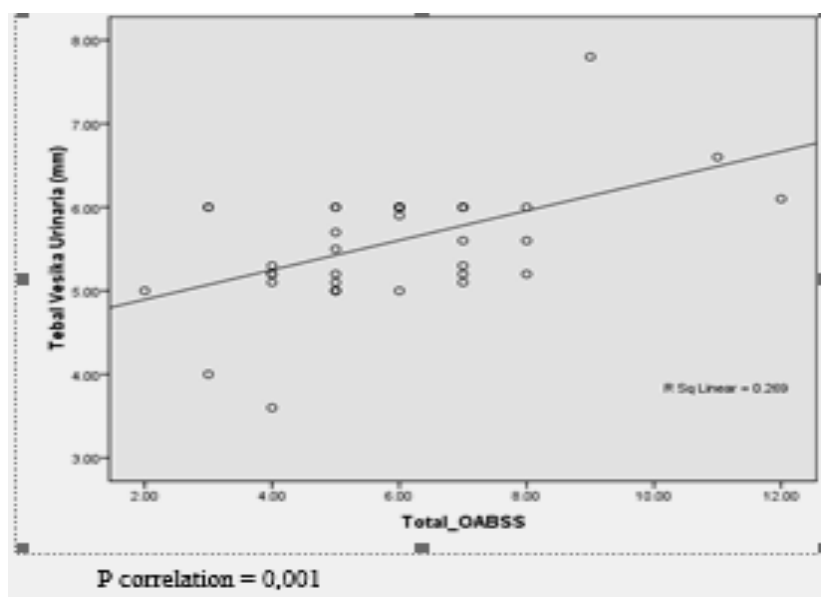

Figure 3. Association between BWT and total OABSS.

Table 3. Association between Pain during Urination and Category of BWT

\begin{tabular}{lccc}
\hline \hline \multirow{2}{*}{$\begin{array}{c}\text { BWT } \\
\text { category }\end{array}$} & $\begin{array}{c}\text { VAS moderate- } \\
\text { severe pain }\end{array}$ & $\begin{array}{c}\text { VAS no pain- } \\
\text { mild pain }\end{array}$ & p \\
\cline { 2 - 3 } & $\mathbf{n}$ & $\mathbf{n}$ & \\
\hline Abnormal $(\geq 5 \mathrm{~mm})$ & 6 & 27 & \\
Normal $(\leq 5 \mathrm{~mm})$ & 0 & 7 & 0.567 \\
Total & 6 & 34 & \\
\hline \hline
\end{tabular}

p association $<0.001$

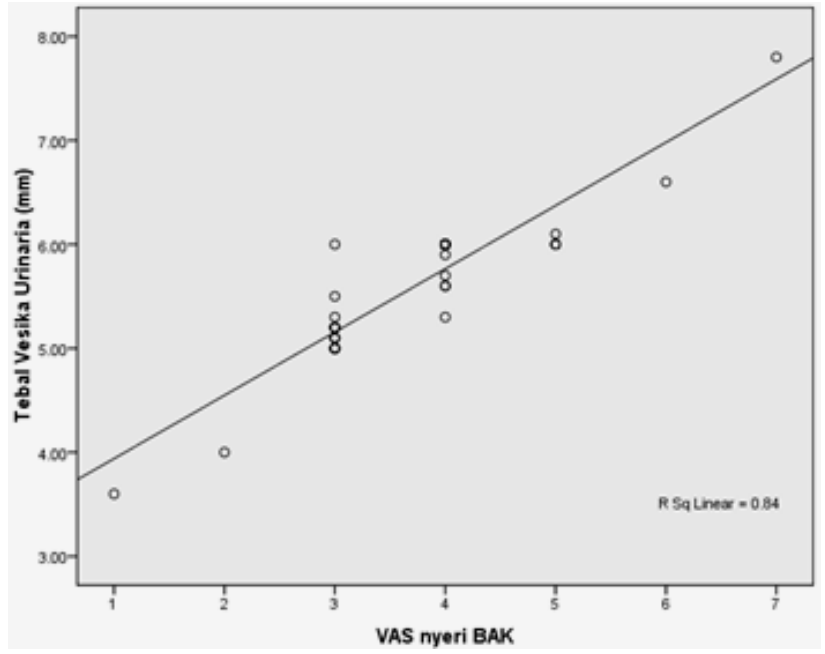

Figure 4. A graph of association between BWT and VAS of urinating pain.

Figure 4 shows significant association $(\mathrm{p}<0.001$, $\mathrm{R}=0.84$ ) between the BWT and painful urination measured in VAS, where the thicker the bladder wall, the more severe the pain. The difference in the significance of findings between the association analysis and association on variable voiding BWT and VAS pain may be due to categorical bias, where the numerical variables are much more representative than categorical data that may lead to biased categorization. Thus, it can be concluded that there is a significant association between these two variables.

Table 4. Association between Painful Urination and Urinary Disorders

\begin{tabular}{lccc}
\hline \hline \multirow{2}{*}{$\begin{array}{c}\text { Urinary } \\
\text { disorders }\end{array}$} & $\begin{array}{c}\text { VAS moderate- } \\
\text { severe pain }\end{array}$ & $\begin{array}{c}\text { VAS no pain- } \\
\text { mild pain }\end{array}$ & $\mathbf{p}$ \\
\cline { 2 - 3 } & $\mathbf{n}$ & $\mathbf{n}$ & \\
\hline Impaired & 4 & 19 & \multirow{2}{*}{0.489} \\
Normal & 2 & 15 & \\
Total & 6 & 34 & \\
\hline \hline
\end{tabular}

Fisher exact test, $p<0.05$

$P$ value $=0.001$

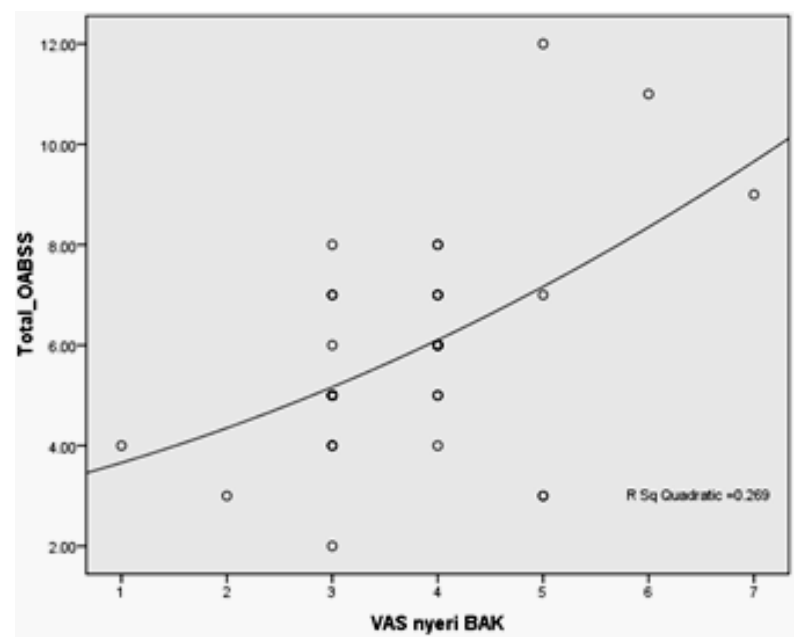

Figure 5. A graph of association between total OABSS and painful urination measure in VAS.

Figure 5 shows that there is a weak, yet significant association ( $p=0.001, R=0.269$ ) between urinary complaints and the VAS of urinating pain, where the higher the total OABSS, the more severe the urinating pain.

The difference in the significance of findings between association analysis and the association between the variables of total OABSS and VAS of urinating pain may be caused by categorical bias, where the numerical variables are much more representative than the categorical data which may lead to biased categorization. Thus, it can be concluded that there is a significant association between these two variables. 


\section{DISCUSSION}

In this study, the diagnosis of urinary disorders/ $\mathrm{OAB}$ is established based on OABSS (overactive bladder Symptom Score) criteria, where the patients complains of urinary frequency $>8 x /$ day, signs of urgency, and nocturia $>1 \mathrm{x} /$ day. The frequency of each symptom was determined by the patient herself and was acquired from the VAS questionnare. ${ }^{12-14}$

We found that urinary disorder occurs more often in women with young age $(62.5 \%)$. This finding is contradictory to the existing theory, where old age causes a decrease in pelvic floor muscle function and a higher risk of developing urinary disorders, especially OAB. However, Dwyer et al. (2002) and Telokan et al. (2006) found no significant association between age and the incidence of urinary disorders, especially OAB. ${ }^{15}$

Statistical analysis found a significant association between BWT with urinary disorders, where in women with BWT $\geq 5 \mathrm{~mm}$ have $12 \mathrm{x}$ the risk of experiencing urinary disorders compared to those with BWT $\leq 5 \mathrm{~mm}$. This finding is consistent with the theory in which repetitive involuntary contractions of the bladder muscle, the pathophysiology of $\mathrm{OAB}$, against the closed sphincter will over time cause hypertrophy of the detrusor muscle (secondary impact) and manifests as the bladder wall thickening (BWT) on ultrasound examination. Nevertheless, analysis association found a weak positive association between BWT and urinary disorders. This may be due to the small and uneven sample size (majority of the samples have BWT $\geq 5 \mathrm{~mm}$ ). ${ }^{16}$

Spearman who association analysis found a significant association between the BWT and the VAS of urinating pain. This is similar to a study by Panayi et al. (2010), and it may be concluded that BWT may reflect the severity of urinary disorders experienced by the respondents. Shu $\mathrm{Yu}$ and Panayi found similar findings to those in this study. However, the cause of the bladder wall thickening, as hypothesized by Shu Yu, may be caused by inflammation or obstruction, two things that have yet to be controlled by the researchers in this study. When bladder wall thickening is caused by inflammatory process, in addition to the findings of urinary disorders, a complaint of pain during urination will also be significant. However, if the thickening is caused by a chronic obstruction, the urinating complaint may not be significant. ${ }^{16,17}$
Similar to the earlier discussion of BWT's association with VAS of urinating pain, a significant positive association was also found between the VAS of micturition pain and urinary disorders. From this finding, it can then be concluded that the VAS of micturition pain is a reflection of the degree of urinary disorders, measured in a total OABSS score. Weak association of these two variables seems to be an uncommon finding. Considering the strong association between BWT and VAS, the association between VAS and urinary disorders should also be strong. VAS of micturition pain is a different variable from VAS of the urinary disorders and is a reflection of "pain" during urination, and so, is highly subjective in each individual, especially if there are other conditions that may increase the pain (such as urinary tract infections, post partum, trauma, etc.), which in this study has yet to be controlled. Thus, it is understandable that this unusual; findings may be due to two main causes: 1) the respondent bias (value of VAS of the micturition pain is highly subjective) and 2) there is no direct association between urinary disorders (total OABSS score) and VAS of micturition pain, and so the association between VAS of micturition pain and urinary disorders is assumed to be similar to the association between VAS of micturition pain and BWT. ${ }^{18-20}$

This research is a pioneer study assessing the association between BWT and urinary problems in Asian societies, and particularly Indonesia. In contrast to research Panayi et al. (2010) which addressed the European population. Researchers did a direct assessment using a questionnaire (primary data) in establishing the diagnosis of urinary disorders. Ultrasound examination was carried out by consultants who are competent in the field of ultrasound.

This research itself also has some crucial drawbacks: urinary tract infections that may cause $\mathrm{OAB}$ and aggregate painful urination were not controlled in this study; the small sample size; and the value of BWT, in particular, which is not normally distributed (the majority of sample was in the $\geq 5 \mathrm{~mm}$ group) may cause the analysis to be biased because of the unequal distribution of numerical variables.

Nevertheless, the result of this study is expected to contribute the understanding of the pathophysiology of urinary disorders, especially in terms of anatomy of the bladder, and may become an 
invasive and inexpensive predictor tool in assessing the degree of urinary disorders.

\section{CONCLUSIONS}

BWT is associated with urinary disorders and painful urination. The thicker the bladder wall, the greater the degree of urinary disorders and micturition pain. Thus, the size of the BWT measured with ultrasonography examination (USG) can be used to assess the status and degree of urinary disorders in women with complaints of pain and urinary disorders.

\section{REFERENCES}

1. Ouslander JG. Management of overactive bladder. NEJM. 2004; 350.8: 786-99.

2. Irwin J, Debra E. Impact of overactive bladder symptoms on employment, social interactions and emotional wellbeing in six European countries. BJU Int. 2006; 97:1 96-100.

3. Junizaf, Santoso BI. Buku Ajar Uroginekologi Indonesia. Himpunan uroginekologi Indonesia. Jakarta. 2011

4. Kelleher Con MJ. Improved quality of life in patients with overactive bladder symptoms treated with solifenacin. BJU Int. 2005; 95.1: 81-5.

5. Nitti V, Taneja S. Overactive bladder: achieving a differential diagnosis from other lower urinary tract conditions. Int Clin Pract. 2005; 59.7: 825-30.

6. Yamaguchi 0 . Defining clinical assessment in overactive bladder. Int Clin Pract. 2004; 58.s140: 4-5.

7. Cardozo L. The overactive bladder syndrome: treating patients on an individual basis. BJU Int. 2007; 99.s3: 1-7.

8. Hashim $\mathrm{H}$, Abrams P. Is the bladder a reliable witness for predicting detrusor overactivity? J Urol. 2006;175.1: 191-4.

9. Dmochowski R. Evaluating the effectiveness of therapies for urinary incontinence. Reviews in urology. 2001; 7-14.

10. Farag FF, Haesakkers JP. Non-invasive thechniques in the diagnosis of bladder storage disorders. Neurol Urodynamics. 2011; 30: 1422-8.
11. Haylen BT, Ridder D, Freeman RM. Swift SE, Berghmans B, Lee J, Monga A, Petri E, et al. Int Urogynecol Association (IUGA)/Int Continence Society (ICS) joint report on the terminology for female pelvic floor dysfunction. Int Urogynecol. 2010; 21: 5-26.

12. Panayi DC, Khullar V. Fernando R, Tekkis P. Transvaginal ultrasound measurement of baldder wall thickness a more reliable approach than transperineal and transabdominal approaches. BJU Int. 2010; 106 : 1519-22.

13. Rachaneni S, Balogun M, Latthe P. Bladder-wall-thickness ultrasound scan in the investigation of LUTS in women: challenges and limitations. Int Urogynecol J. 2013; 24: 7258.

14. Fujihara A, Ukimura O, Honjo H, Iwata T, Ueda T, Matsugami $\mathrm{T}$, et al. Urge perception index of bladder hypersensitivity. J Urogynecol. 2013; 189: 1797-803.

15. Panayi DC, Tekkis RF, Hendricken C, Khullar V. Ultrasound measurement of bladder wall thickness is associated with the overactive bladder system. Neurol Urodynamics. 2010; 29: $1295-8$.

16. Lekskulchai 0, Dietz HP. Detrusor wall thickness as a test for detrusor overactivity in women. Ultrasound Obstet Gynecol. 2008; 32: 535-9.

17. Gormley EA, Lightner DJ, Burgio KL, Chai TC, Clemens JQ Culkin DJ, et al. Diagnosis and Treatment of Overactive Bladder (Non-Neurogenic) in Adults: AUA/SUFU Guideline. Am Urol Association Edu Research, Inc.2012;188(supp 6):245563.

18. Wennberg AL, Altman D, Lundholm C, Klint A, Iliadou A, Peeker R, et al., Genetic Influences Are Important for Most But Not All Lower Urinary Tract Symptoms: A PopulationBased Survey in a Cohort of Adult Swedish Twins. Eur Urol. 2011; 59(6): 1032-8.

19. Palma T, Raimondi M, Souto S, Fozzatti C, Palma P, Riccetto C. Association between body mass index and overactive bladder symptoms in pre-menopausal women. Rev Assoc Med Bras 2014; 60(2): 111-7.

20. Wu SY, Jhang JF, Jiang YH, Kuo HC. Increased bladder wall thickness is associated with severe symptoms and reduced bladder capacity in patients with bladder pain syndrome. J Urol. 2015; 6: 154. 